J I I | P

\title{
Perilaku konsumsi masyarakat terhadap pangan berbahan dasar sagu di Pekanbaru, Indonesia
}

\section{Consumer behavior of sago-based food industry in Pekanbaru, Indonesia}

\author{
Rini Nizar*, Anto Ariyanto, Asgami Putri \\ Department of Agribusiness, Faculty of Agriculture, Universitas Lancang Kuning, Pekanbaru, Indonesia
}

ARTICLE INFO

\begin{tabular}{ll} 
Article History & \\
Received: & February 1, 2021 \\
Accepted: & Augustus 7, 2021 \\
Published: & Augustus 29, 2021 \\
\hline
\end{tabular}

Keywords:

consumer behavior,

sago,

gluten-free,

food diversification

Cite this:

J. IIm. Pertan., 2021, 18 (1) 37-42

DOI:

https://doi.org/10.31849/jip.v18i1.6062

\section{ABSTRACT}

Riau Province makes sago (Metroxylon sp) one of the alternative sources of gluten-free food. Sago has been processed into food ingredients ranging from traditional with local wisdom approaches to modern. The processing of sago was recorded to produce hundreds of food menu creations. However, from various kinds of processed foods made from sago, this is still constrained by the low level of consumption of sago-based foods. It is presumably because the community still has many food sources as a substitute for rice, such as cassava, corn, and others. If viewed from the potential of raw materials for sago owned by Riau Province, sago can be the primary source of food diversification, one of the steps to reduce dependence on the primary carbohydrate source obtained from rice. Therefore, analysis is needed to determine what factors influence a consumer's decision to consume food products made from sago. The method used in this study was a survey method by accidental random sampling. The research model used was a logistic regression model. The survey location was performed in Pekanbaru as the capital city of Riau Province. Testing on the significance of the model was carried out using the Likelihood Ratio Test and the Wald Test. The results showed that the processed sago that consumers often consume was sago noodles (54\%). As a local food, the sago was determined mainly by the processed and the price of sago. Therefore, to maintain the sustainability of sago, the government needs to play a role.

\section{INTRODUCTION}

Provinsi Riau merupakan salah satu provinsi penghasil sagu terbesar di Indonesia. Kabupaten Pelalawan, Siak, Indragiri Hilir dan Kepulauan Meranti merupakan Kabupaten yang memiliki ekologi yang sangat sesuai untuk pertumbuhan tanaman sagu dimana Kabupaten ini terletak di wilayah pesisir dengan daerah rawa dan bergambut (Hardison and Pramana, 2020). Sebagai bahan pangan, sagu dapat dimanfaatkan sebagai sumber alternatif karbohidrat dan bebas gluten. Kadar karbohidrat sagu setara dengan karbohidrat yang terdapat pada tepung beras, singkong, dan kentang (Hidayat and Suptijah, 2014). Sagu dapat diolah menjadi bahan pangan olahan salah satunya yang paling sering dijumpai adalah mie sagu. Sagu merupakan tanaman penghasil karbohidrat dengan nilai ekonomi yang masih murah dan banyak tersedia di daerah- daerah Provinsi Riau (Nurmalina and Astuti 2012). Dalam hal mengolah bahan pangan dengan bahan baku sagu, Provinsi Riau telah berhasil menciptakan kreatifitas dengan menghasilkan 369 jenis menu makanan berbahan dasar sagu mulai dari pangan tradisional seperti sepolet, gedegob, roti jala, lontong, cendol, maupun bahan pangan modern seperti mie dan tepung sagu untuk berbagai olahan kue (Syukur, 2016). Sentra produksi sagu di Provinsi Riau terdapat di Kabupaten Kepulauan Meranti, banyak produk pangan dengan bahan baku sagu diproduksi oleh industri rumah tangga di daerah tersebut (Elida and Vaulina 2018).

Pengeluaran rumah tangga untuk konsumsi pangan (IDR/kapita/bulan) di Indonesia, rata-rata masih didominasi oleh beras sebagai sumber karbohidrat. Di Kota Pekanbaru, rata-rata pengeluaran untuk bahan pangan 
sumber karbohidrat terbesar adalah padi-padian sebesar $20.15 \%$ dan yang terkecil untuk umbiumbian sebesar 2.06\% (Syaifullah, et al. 2017). Namun, tingginya rata-rata pengeluaran untuk konsumsi pangan sumber karbohidrat seperti beras tidak diimbangi dengan peningkatan produksi beras. Rendahnya pertumbuhan produksi beras dipengaruhi oleh berbagai faktor utama, salah satunya adalah lahan produktif yang berangsur-sangsur berkurang. Hal ini berarti bahwa peluang bahan pangan berbahan baku sagu cukup besar dikala tingginya pengeluaran konsumsi beras tidak diimbangi oleh peningkatan produksi beras.

Dewasa ini, perilaku konsumen dalam mengonsumsi suatu produk/barang adalah memaksimumkan kepuasan dari suatu barang yang dikonsumsinya (Boediono, 2002). Banyak faktor yang mempengaruhi keputusan masyarakat dalam mengonsumsi suatu produk diantaranya adalah harga, pendapatan rumah tangga, dan preferensi rumah tangga terhadap barang yang akan dikonsumsi (Wahyuni et al., 2016). Pemenuhan kepuasan dalam mengonsumsi ternyata juga erat kaitannya dengan persepsi masyarakat terhadap barang yang dikonsumsi (Abidin and Musadar, 2018). Preferensi setiap rumah tangga berbeda-beda disebabkan oleh adanya perbedaan karakteristik, seperti pendidikan, jumlah anggota keluarga, kebiasaan, budaya, lokasi tempat tinggal, dan tingkat sosial (Permata, 2000).

Rendahnya konsumsi pangan berbahan baku sagu disebabkan karena masyarakat masih memiliki banyak pilihan dalam memilih bahan pangan lain sebagai sumber karbohidrat pengganti beras, seperti singkong, jagung dan umbi-umbian lainnya. Potensi bahan baku sagu sebagai sumber pangan alternatif yang mengandung karbohidrat dalam rangka diversifikasi pangan merupakan salah satu langkah untuk mengurangi ketergantungan sumber karbohidrat utama seperti beras, singkong, jagung dan umbi-umbian lainnya dengan melakukan suatu analisis untuk mengetahui faktor-faktor apa saja yang mempengaruhi keputusan seorang konsumen dalam mengonsumsi produk pangan berbahan baku sagu di Kota Pekanbaru.

\section{RESEARCH METHODS}

Metode yang digunakan dalam penelitian ini adalah metode survei dengan mengambil responden secara acak ketemu (accidental random sampling) sebanyak 100 orang, dimana responden dipilih atas pertimbangan tertentu, yaitu siapa saja yang pernah mengonsumsi makanan berbahan baku sagu dan secara berulang. Cooper and Emory (1995) menyatakan bahwa untuk populasi yang tidak teridentifikasi secara pasti jumlahnya, sampel ditetapkan secara langsung sebesar 100 responden. Asumsi tersebut menunjukkan bahwa ukuran (jumlah) absolut sampel lebih penting daripada ukuran proporsinya terhadap populasi. Jumlah sampel 100 dianggap sudah memenuhi syarat suatu sampel yang representative. Pengumpulan data primer diambil dengan menggunakan kuesioner, data sekunder diambil dari referensi yang terkait yang terdiri dari buku referensi, penelitianpenelitian terdahulu serta jurnal-jurnal seputar perilaku konsumsi. Model dalam penelitian ini menggunakan regresi logistic. Regresi logistic memiliki distribusi data yang tidak normal (Kuncoro, 2013). Analisis yang digunakan dalam penelitian ini menggunakan metode estimasi Maximum Likelihood yang bertujuan mencari koefisien regresi sehingga probabilitas kejadian dari variabel dependen bisa setinggi mungkin atau semaksimum mungkin (Widarjono 2015).

Keputusan seseorang untuk mengonsumsi makanan berbahan dasar sagu merupakan variabel dependen yang mempunyai dua kelas. Jawaban yang akan diperoleh adalah mereka yang mengonsumsi makanan berbahan dasar sagu atau mereka yang tidak mengonsumsi makanan berbahan dasar sagu. Dalam model regresi dimana variabel bersifat kualitatif maka variabel baik dependen maupun independen harus dikuantitatifkan agar regresi bisa dilakukan dengan memberi nilai 1 jika variabel mempunyai atribut dan nilai o jika tidak mengandung atribut (Widarjono, 2015).

Untuk melakukan pengujian terhadap signifikansi model, digunakan Uji Rasio Likelihood dan Uji Wald (Gujarati 2003). Statistik Uji Rasio Likelihood bertujuan untuk menguji kesesuaian model dengan melihat pengaruh semua variabel bebas terhadap variabel tidak bebas di dalam model. Sedangkan Uji Wald bertujuan untuk menguji kemaknaan tiap variabel satu demi satu. Keputusan seseorang untuk mengonsumsi makanan berbahan dasar sagu merupakan variabel dependen didalam model regresi logistik. Sementara variabel independen yang dimasukkan kedalam model adalah: asal daerah, tingkat pendidikan, umur, jenis makanan olahan dari sagu, pendapatan dan harga sagu (Permata, 2000; Wahyuni et al,. 2016; Abidin \& Musadar, 2018). Variabel jenis makanan olahan dari sagu dimasukkan kedalam model berdasarkan sangat bervariasinya olahan pangan dengan bahan baku sagu di Provinsi Riau.

Sementara itu, untuk pengolahan data secara statistik menggunakan SPSS versi 22.0, 2020. 


\section{RESULTS AND DISCUSSIONS}

Karakteristik demografi

Adapun karakteristik demografi dari konsumen dalam penelitian ini dikelompokkan ke beberapa bagian sebagaimana yang terlihat pada Tabel 1 .

Tabel 1. Karakteristik demografi $(n=100)$

\begin{tabular}{lc}
\hline \multicolumn{1}{c}{ Karakteristik } & Persentase (\%) \\
\hline Asal Daerah & $88 \%$ \\
Pekanbaru & $12 \%$ \\
Luar Pekanbaru & \\
Tingkat Pendidikan & $4 \%$ \\
Tidak Sekolah & $8 \%$ \\
SD & $26 \%$ \\
SMP & $58 \%$ \\
SMA & $4 \%$ \\
Universitas & \\
Umur (tahun) & $28 \%$ \\
$19-28$ & $22 \%$ \\
$29-38$ & $37 \%$ \\
$39-48$ & $13 \%$ \\
$49-58$ & \\
Pendapatan (IDR) & \\
$<2$ juta IDR & $1 \%$ \\
$2-4$ juta IDR & $21 \%$ \\
$4-6$ juta IDR & $58 \%$ \\
$>6$ juta IDR & $20 \%$ \\
\hline 1 ( USD = 14,500 IDR & \\
\hline
\end{tabular}

Dari Tabel 1 dilihat bahwa kebanyakan responden yang disurvei memang berdomisili di Pekanbaru (88\%) dan sisanya 12\% berasal dari luar Pekanbaru. Tingkat pendidikan responden pada umumnya tamatan Sekolah Menengah Atas (SMA) sebanyak 58\% dan Sekolah Menengah Pertama (SMP) sebanyak 26\%. Sementara umur responden pada umumnya berkisar antara 39 48 tahun (37\%), dan berkisar 29-38 tahun (22\%).

Pada Tabel 1 profil pendapatan responden yang menjelaskan pendapatan yang diterima responden tiap bulannya juga dapat dilihat, dimana menunjukkan pendapatan responden pada penelitian ini memiliki rata-rata antara 4 6 juta, yaitu sebanyak 58\%; antara $2-4$ juta sebanyak 21\% dan besar dari IDR 6.000.000 sebanyak 20\%. Pada umumnya responden memperoleh pendapatan di atas Upah Minimum Kerja (UMK) Kota Pekanbaru.

\section{Preferensi konsumen}

Preferensi konsumen dalam mengonsumsi pangan berbahan sagu dapat dilihat pada Tabel 2.

Tabel 2. Preferensi konsumen mengonsumsi menurut jenis olahan sagu $(n=100)$

\begin{tabular}{lcc}
\hline \multicolumn{1}{c}{ Jenis Olahan Sagu } & Responden & Persentase (\%) \\
\hline Tidak Ada Olahan & 20 & $20 \%$ \\
Mie Sagu & 54 & $54 \%$ \\
Ongol-Ongol & 6 & $6 \%$ \\
Kerupuk Sagu & 5 & $5 \%$ \\
Kue Lapis & 8 & $8 \%$ \\
Bubur & 7 & $7 \%$ \\
\hline
\end{tabular}


Tabel 2 menunjukkan bahwa 54\% responden mengonsumsi mie sagu, kemudian 20\% tanpa olahan. Tanpa olahan maksudnya adalah tepung sagu atau olahan yang diperoleh dari pemrosesan teras batang rumbia atau pohon sagu (Metroxylon sagu. Rottb).

Omnibus Test of Model Coefficients menyajikan uji serentak semua koefisien variabel di dalam regresi logistik. Nilai Chi-Squares didalam tabel sebesar 66.811 dengan nilai signifikan $0.000<0.05$, sehingga dapat disimpulkan bahwa Asal Daerah $\left(\mathrm{X}_{1}\right)$, Tingkat Pendidikan $\left(\mathrm{X}_{2}\right)$, Jenis Olahan Sagu $\left(\mathrm{X}_{3}\right)$, Pendapatan $\left(\mathrm{X}_{4}\right)$, Umur $\left(\mathrm{X}_{5}\right)$ dan Harga $\left(\mathrm{X}_{6}\right)$ secara simultan mempengaruhi keputusan seseorang dalam mengonsumsi jenis pangan dengan bahan baku sagu.

Sementara itu, uji goodness of fit model logit berdasarkan nilai dari Nagelkerke $R$ Square yang besar nya 0.748. Angka ini berarti bahwa variabel Asal Daerah $\left(\mathrm{X}_{1}\right)$, Tingkat Pendidikan $\left(\mathrm{X}_{2}\right)$, Jenis Olahan Sagu $\left(\mathrm{X}_{3}\right)$, Pendapatan $\left(\mathrm{X}_{4}\right)$,
Umur $\left(\mathrm{X}_{5}\right)$ dan Harga $\left(\mathrm{X}_{6}\right)$ di dalam model logit mampu menjelaskan perilaku konsumsi masyarakat terhadap pangan dengan bahan baku sagu sebesar $74.8 \%$ dan terdapat $25.2 \%$ faktor lain yang tidak dimasukkan ke dalam model. Uji Hosmer dan Lemeshow mengungkapkan bahwa hasil uji chi squares menunjukkan nilai signifikansi $0.909>0.05$ sehingga nilai probabilitas yang diprediksi sesuai dengan probabilitas yang diobservasi.

Classification table menunjukkan seberapa baik model mengelompokkan kasus ke dalam dua kelompok baik yang tidak mengonsumsi sagu maupun yang mengonsumsi sagu. Perilaku konsumsi seseorang pada saat tidak mengonsumsi Keakuratan prediksi secara menyeluruh sebesar $94 \%$ Sedangkan keakuratan prediksi yang tidak mengonsumsi sagu dan mengonsumsi sagu masing-masing sebesar $81,8 \%$ dan 97,4 \%, seperti yang terlihat pada Tabel 3 .

Tabel 3. Keakuratan prediksi classification table

Predicted

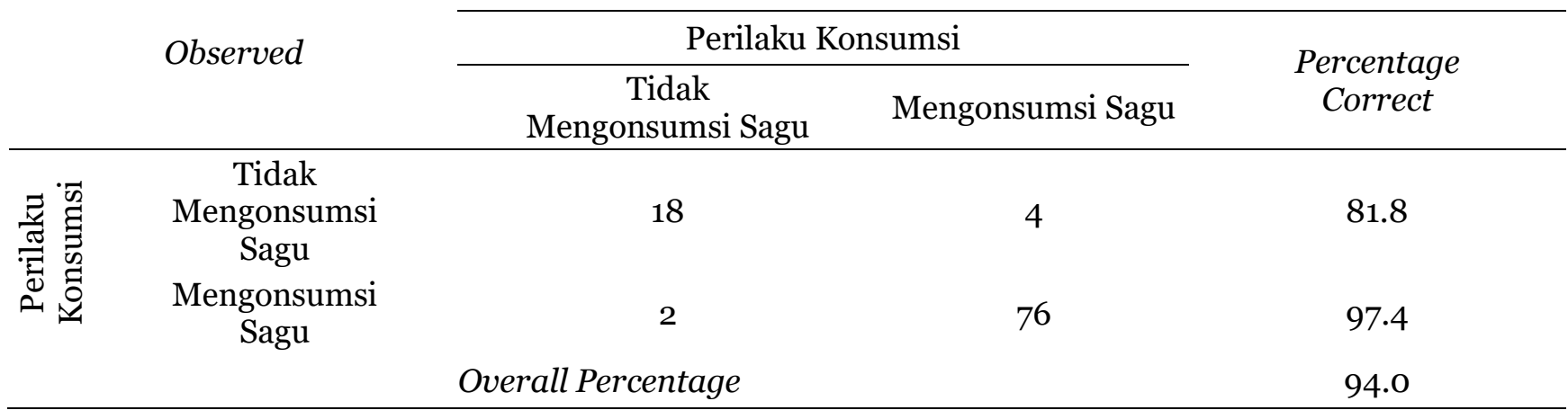

Tabel 4. Hasil analisis regresi logistik

\begin{tabular}{lrrrrr}
\hline \multicolumn{1}{c}{ Variabel } & \multicolumn{1}{c}{ B } & \multicolumn{1}{c}{ S.E. } & \multicolumn{1}{c}{ Wald } & \multicolumn{1}{c}{ Sig. } & Exp(B) \\
\hline AD_X ${ }_{1}$ & -.539 & 1.478 & .133 & .716 & .584 \\
Pddk_X & -.663 & 1.716 & .149 & .699 & .515 \\
JO_X & 6.098 & 1.233 & 24.471 & .000 & 445.087 \\
Pdptn_X & .425 & .365 & 1.352 & .245 & 1.529 \\
Umur_X & .005 & .049 & .009 & .925 & 1.005 \\
Hrg_X & -.256 & .125 & 4.215 & .040 & .774 \\
Constant & -.494 & 3.718 & .018 & .894 & .610 \\
\hline
\end{tabular}

Berdasarkan Tabel 4, model persamaan regresi logistik dapat diformulasikan sebagai berikut:

$\ln \left[\frac{p i}{(1-p i)}\right]=-0.494-0.539 X_{1}-0.663 X_{2}+$ $6.098 X_{3}+0.425 X_{4}+0.005 X_{5}-0.256 X_{6}+\varepsilon$
Uji signifikansi variabel independen secara parsial dengan menggunakan uji statistika wald dapat dilihat dalam Tabel 4. Variabel jenis olahan sagu $\left(\mathrm{X}_{3}\right)$ dan Harga sagu $\left(\mathrm{X}_{6}\right)$ berpengaruh secara signifikan terhadap keputusan seseorang dalam mengonsumsi jenis pangan dengan bahan baku sagu dilihat dari masing-masing nilai signifikansi sebesar $0.000<0.05$ dan $0.040<$ 
o.05. Sebaliknya uji signifikansi variabel lainnya seperti Asal daerah $\left(\mathrm{X}_{1}\right)$, tingkat pendidikan $\left(\mathrm{X}_{2}\right)$, pendapatan $\left(\mathrm{X}_{4}\right)$ dan Umur $\left(\mathrm{X}_{5}\right)$ tidak berpengaruh secara signifikan terhadap keputusan seseorang untuk mengonsumsi bahan pangan sagu.

Besarnya pengaruh ditunjukkan dengan nilai Exp (B) atau disebut juga Odds ratio (OR). Odds ratio untuk Jenis olahan sagu $\left(\mathrm{X}_{3}\right)$ sebesar 445.1 yang artinya rasio kemungkinan mengonsumsi jenis pangan dengan bahan baku sagu dalam bentuk olahan sebesar 445,1 kali, sehingga dapat disimpulkan bahwa semakin banyak variasi olahan pangan sagu maka peluang untuk mengonsumsi sagu akan meningkat. Odds ratio untuk harga sagu $\left(\mathrm{X}_{6}\right)$ sebesar 0.774 . Karena koefisien b bertanda negatif maka nilai tersebut dapat diartikan bahwa jika harga sagu turun sebesar 1 unit (IDR 1.00o) maka rasio kemungkinan mengonsumsi jenis pangan dengan bahan baku sagu naik sebesar 0.774 kali.

Dari hasil pengujian, faktor-faktor yang dapat mempengaruhi keputusan seseorang dalam mengonsumsi sagu adalah jenis olahan dan harga sagu. Berarti, semakin banyaknya variasi jenis olahan pangan berbahan baku sagu sangat menentukan apakah seseorang akan mengonsumsinya. Di Provinsi Riau sendiri dikenal beberapa jenis makanan dari olahan bahan pangan sagu, paling banyak ditemui diantaranya mie sagu, kue lapis, kerupuk sagu, ongol-ongol, bubur, kepurun, gobak, sagu rendang, sagu lemak/sagon, lempeng sagu, dan lainnya.

Harga sagu secara signifikan berpengaruh negatif terhadap keputusan seseorang dalam mengonsumsi jenis pangan dengan bahan baku sagu. Ini menunjukkan bahwa semakin mahal harga sagu maka peluang responden untuk mengonsumsi sagu semakin kecil. Sukirno (2011) menegaskan bahwa hukum permintaan adalah hubungan antara harga dan jumlah permintaan suatu barang yang berbanding terbalik (negatif) dengan asumsi ceteris paribus (faktor-faktor lain dianggap tetap) sehingga koefisien harga sagu secara signifikan berpengaruh negatif terhadap keputusan seseorang dalam mengonsumsi bahan pangan sagu yang berarti bahwa semakin mahal harga sagu maka peluang responden untuk mengonsumsi sagu semakin kecil

\section{CONCLUSIONS}

Faktor-faktor yang mempengaruhi keputusan seorang konsumen dalam mengonsumsi pangan berbahan baku sagu, yaitu jenis olahan sagu dan harga sagu. Sehingga, keputusan konsumen dalam mengonsumsi sagu sangat ditentukan ketika sagu sudah diolah menjadi pangan yang siap dikonsumsi. Salah satu olahan sagu yang paling disukai oleh masyarakat Kota Pekanbaru adalah mie sagu. Dengan harga yang semakin murah, maka peluang seorang konsumen dalam mengonsumsi sagu ikut meningkat atau sebaliknya disaat harga sagu semakin mahal maka peluang seorang konsumen dalam mengonsumsi sagu ikut menurun.

Hasil penelitian ini dapat digunakan sebagai masukan bagi dinas terkait dalam melakukan pengembangan atau pendampingan pada berbagai macam jenis olahan sagu, serta dalam mengendalikan harga sagu sehingga dapat meningkatkan pola konsumsi pangan alternatif tersebut. Sosialisasi dan promosi berbagai jenis pangan berbahan baku sagu dalam rangka diversifikasi pangan alternatif perlu dilakukan oleh Dinas Ketahanan Pangan agar sagu menjadi pilihan pangan alternatif bagi masyarakat, terutama bagi konsumen yang membutuhkan makanan bebas gluten.

\section{REFERENCES}

Abidin, Z., and Musadar. (2018). Analisis Persepsi Masyarakat Terhadap Pangan Lokal Sagu di Kota Kendari Sulawesi Tenggara. Berkala Ilmiah AGRIDEVINA, 7(1): 1-13.

Boediono. (2002). Ekonomi Mikro. BPFE.

Cooper, D. R., and Emory, C. W. (1995). Business Research Methods. 5 th Ed. Inc. New York.

Elida, S., and Vaulina, S. (2018). "Diversifikasi Produk Berbasis Sagu Sebagai Alternatif Kemandirian Pangan Di Kecamatan Tebing Tinggi Timur Kabupaten Kepulauan Meranti Provinsi Riau.” In Peran Keanekaragaman Hayati Untuk Mendukung Indonesia Sebagai Lumbung Pangan Dunia. Universitas Sebelas Maret, 120-32.

Gujarati, D. N. (2003). Basic Econometrics. Fourth Edi. West Point: United States Military Academy.

Hardison and Pramana, A. (2020). Potensi Tanaman Sagu Sebagai Produk Pangan Lokal Di Provinsi Riau. Journal Agribusiness Future, 2(1).

Hidayat, T., and Suptijah, P. (2014). Karakterisasi Tepung Buah Lindur (Brugeira Gymnorrhiza) Sebagai Beras Analog dengan Penambahan Sagu dan Kitosan. Jurnal Pengolahan Hasil Perikanan Indonesia, 16(3): 1-1.

Kuncoro, M. (2013). Metode Riset Untuk Bisnis Dan Ekonomi Bagaimana Meneliti Dan Menulis Tesis. Erlangga.

Nurmalina, R., and Astuti, E.P. (2012). Analisis Preferensi Dan Kepuasan Konsumen Terhadap Beras di Kecamatan Mulyorejo Surabaya Jawa Timur. Jurnal Sains 
Terapan, 1(1), 42-47.

Permata, D. L. J. (2000). Preferensi Masyarakat Terhadap Lanskap Visual Pemukiman (Studi Kasus Pemukiman Di Kabupaten Cianjur Dan Kotamadya Bogor). Bogor.

Sukirno, S. (2011). Mikro Ekonomi Teori Pengantar Edisi Ketiga. Edisi KEti. Rajawali Pers.

Syaifullah, M., Eliza, and Tarumun, S. (2017). Analisis Pendapatan Dan Pengeluaran Rumah Tangga Pada Kawasan Rumah Pangan LEstari (KRPL) di Kota Pekanbaru. Jurnal Online Mahasiswa Faperta UR, 4(1), 1-10.
Syukur, M. (2016, Oct 26). Riau Pecah Rekor, Sagu Diolah Jadi 369 Makanan. Liputan 6. https://www.liputan6.com/regional/read/2 635675/riau-pecah-rekor-sagu-diolah-jadi369-makanan

Wahyuni, D., Purnastuti, L., and Mustofa. (2016). Analisis Elastisitas Tiga Bahan Pangan Sumber Protein Hewani Di Indonesia. Jurnal Economia, 12(1): 43.

Widarjono, A. (2015). Analisis Multivariat Terapan Dengan Program SPSS, AMOS Dan SMARTPLS. Kedua. UPP STIM YKPN. 